\title{
PENCIPTAAN PERTUNJUKAN TEATER BANOWATI SANG PELAKOR: SEBUAH IMPLEMENTASI METODE PENYUTRADAAN AUGUSTO BOAL
}

\author{
Wahid Nurcahyono \\ Institut Seni Indonesia Yogyakarta, Indonesia
}

\begin{abstract}
Abstrak: Penciptaan pertunjukan teater ini dilatari oleh fenomena pelakor yang dewasa ini terasa marak. Penciptaan karya ini menggunakan pendekatan teori interteks dan feminis dalam mengolah kisah naskah. Pemahaman secara intertekstual bertujuan untuk menggali secara bebas makna-makna yang terkandung dalam sebuah teks kisah asmara Putri Banowati kepada Raden Arjuna. Metode dalam proses penciptaan ini menggunakan metode penciptaan yang dikembangkan oleh Boal (2000), yang secara unik merubah penonton (objek) menjadi pemain (subjek). Proses penciptaan ini terbukti mampu menciptakan komunikasi yang unik antara partisipan, aktor, dan pengamat. Hal tersebut bisa dimanfaatkan untuk mendalami sebuah persoalan sosial di masyarakat yang mungkin sulit diungkapkan terutama pada isu yang berbenturan dengan nilai-nilai dan dianggap tabu pada suatu lingkungan.
\end{abstract}

Kata kunci: Teater, pelakor, Boal, interteks, feminisme

\begin{abstract}
The creation of this theatre performance is based on issues of people in that has spiked up recently. This creation uses intertext and feminism theoretical approach in arranging the playscript. Intertextual understanding aims to search deeper on the implicit meaning within the romance of Putri Banowati and Raden Arjuna. The method used in the art creation process is the method developed by Boal (2000) that uniquely changes the audience (the object) into actors (the subject). This art creation process is proven to be able to create a unique communication between participant, actors, and observers. Such relationship can be made use for analysing the social problem in the society that might have been too risque to be openly discussed, especially in the issues considered taboo in a community.
\end{abstract}

Key word: Theatre, affair, Boal, intertext, feminism

\section{Pendahuluan}

Peristiwa viral yang menyedot perhatian bersama baru-baru ini adalah tentang beredarnya sebuah video berdurasi kurang lebih 10 menit sempat menjadi perhatian kaum netizen dan penggiat sosial media. Peristiwa keseharian yang sebenarnya merupakan peristiwa dinamika dalam berumah tangga menjadi konsumsi publik yang sejenak memalingkan perhatian dari persoalan-persoalan politik maupun gejolak ekonomi dan sosial lainnya yang lebih besar. Hal yang seharusnya hanya layak menjadi persoalan pribadi diungkap sedemikian rupa sehingga menjadi heboh namun justru dibeberapa kalangan tertentu dianggap sebagai hal yang berlebihan dan terkesan murahan.

Sedangkan pada beberapa kalangan lain dianggap sebagai hiburan meski yang dipertontonkan adalah sebuah ironi. Di lapisan masyarakat lain hal itu dianggap jauh dari nilai-nilai kepantasan dan amoral. Meski demikian ada juga yang justru 
memanfaatkannya menjadi lahan pendapatan yang menguntungkan secara ekonomi dengan memviralkannya melalui media internet. Kita pernah mendengar istilah yang tergolong baru yaitu sekitar setahun ini yang berfungsi untuk memberi label bagi seorang perempuan yang berposisi menjalin hubungan cinta dengan lelaki bernotabene telah menjalin ikatan resmi atau kesepakatan tertentu dengan pasangannya. Ya, PELAKOR merupakan kepanjangan dari PErebut LAki Orang. Akhir-akhir ini netizen disuguhi oleh video seorang perempuan yang sedang dicaci maki sebagai pelakor sambil dilempari uang kertas ratusan ribu begitu banyak oleh seorang perempuan lain yang mengaku sebagai istri sah seorang lelaki. Dalam waktu beberapa hari sesudahnya kemudian bermunculan video-video serupa yang bermaksud memparodikannya.

Melihat fenomena tersebut terbentuklah beberapa pandangan dalam kelompok-kelompok diskusi formal maupun non formal di seminar maupun warung kopi. Beberapa pihak membenarkan sikap si ibu yang mencaci sang pelakor, namun beberapa pihak lain juga menyalahkan si lelaki, dan tak jarang yang justru menyalahkan si Ibu atau perempuan pemilik syah lelaki itu. Perbincangan menarik melahirkan opini yang saling beradu secara kuat. Dalam hal ini mereka saling melontarkan argument sesuai sudut pandang dan latar belakang pengalaman yang berlain-lainan. Tak luput pula pandangan dari sisi penggiat atau aktifis persamaan hak perempuan dan kaum feminisme. Kesimpulan menjadi beragam dan agak sulit untuk menentukannya sebagai satu kebenaran yang mutlak.

Sedangkan konselor dan terapis dari Biro Konsultasi Psikologi Westaria, Anggia Chrisanti menjelaskan ada beberapa kesalahan nyata sehingga seseorang rentan dan dengan mudahnya dicap sebagai pelakor. Pelakor atau valakor adalah istilah untuk seseorang yang merebut pasangan lelaki atau suami orang lain. Berikut ini ciricirinya (dikutip dari Tempo.co):

a. Diduga memiliki kedekatan spesial dengan pasangan, khususnya suami, orang lain, baik terkait pekerjaan maupun tidak.

b. Banyak ditemukan bukti dan saksi kebersamaan, bahkan di luar kepentingan pekerjaan.

c. Bukti pembicaraan melalui telepon atau chating yang dianggap tidak biasa. Misalnya, terlalu sering dan atau dengan bahasa atau panggilan yang dianggap tidak biasa, dan atau dengan konten yang tidak seharusnya, terlalu perhatian atau terlalu vulgar.

d. Ditemukan beberapa pemberian barang, baik barang sungguhan maupun bukti transfer uang dalam jumlah dan intensitas yang tidak biasa.

e. Kedekatan berbanding lurus dengan munculnya informasi keretakan rumah tangga seseorang yang sedang dekat dengan orang tersebut. Terlebih jika sampai berpisah.

Kemudian apa yang menyebabkan seseorang menjadi Pelakor? Perbuatan yang (curang). Curang adalah berbuat tidak jujur atau curang yang bertujuan untuk memperoleh keuntungan secara sepihak, misalnya mencontek saat ujian, korupsi, dan perselingkuhan. Menurut Mellisa Grace, M.Psi., Psikolog, ada beberapa alasan yang membuat seseorang dapat melakukan curang, antara lain: dilakukan oleh pelakor tersebut sama halnya dengan perbuatan curang

a. Faktor karakteristik kepribadian seseorang yang manipulatif. Karakteristik manipulatif adalah kecenderungan seseorang untuk memanfaatkan atau memanipulasi situasi 
untuk memperoleh kepentingan pribadi. Karakteristik kepribadian seseorang yang kurang memiliki rasa empati kepada orang lain. Empati adalah kemampuan seseorang untuk merasakan, memahami dan melihat sudut pandang orang lain. Jika seseorang memiliki rasa empati yang kurang maka ia tidak mampu merasakan bahwa ada pihakpihak yang dirugikan dari perilakunya. Karakteristik kepribadian seseorang yang narsis. Karakteristik narsistik adalah perasaan diri yang berlebihan, sehingga seseorang merasa bahwa dirinya yang paling hebat, paling berkuasa, paling cantik atau tampan, paling pantas memperoleh perlakuan istimewa, padahal sesungguhnya perilaku tersebut merupakan bentuk kompensasi dari perasaan rendah diri yang dimiliki oleh seseorang. Ketidakmampuan seseorang berkomunikasi secara terbuka mengenai pikiran dan perasaannya kepada orang lain tanpa menyakiti dirinya dan orang lain. Seseorang yang tidak mampu bersikap terbuka seringkali menggunakan curang sebagai bentuk tindakan untuk mengekspresikan kekesalannya, amarahnya, dan dendam kepada orang lain.

b. Faktor Situasional, seseorang yang melakukan curang telah terbiasa atau belajar tidak terlalu mementingkan nilainilai kejujuran dari sebuah situasi. Hal ini dapat terjadi ketika seseorang dibesarkan dalam lingkungan yang kurang menekankan pentingnya nilainilai kejujuran.

c. Adanya keuntungan Sekunder, seseorang menganggap bahwa perilaku curang lebih mendatangkan banyak keuntungan dibandingkan berperilaku jujur.
Misalnya dengan berperilaku curang, beberapa orang merasa lebih cepat memperoleh status sosial, lari dari tanggungjawab, lebih memperoleh perhatian, lebih cepat kaya, dan sebagainya. Parahnya, para pelakor tersebut berusaha menyalahkan pasangan atau korbannya untuk melepaskan diri dari tanggungjawab atas perilakunya sendiri. Padahal perilaku curang atau selingkuh tidak pernah disebabkan oleh faktor karakteristik korban.

Apakah perilaku curang bisa disembuhkan? Pola perilaku curang tersebut akan cenderung menetap dan berulang, meski bentuk perilakunya bisa berbagai macam, tidak selalu selingkuh. Perilaku curang bisa disembuhkan atau akan berhenti jika muncul keinginan untuk berubah dari diri seseorang tersebut. Lebih lanjut, pelakor yang ingin berubah dapat meminta bantuan atau berkonsultasi ke psikolog atau para ahli dibidangnya.

Bagaimana beragam opini dari masyarakat menanggapi fenomena di atas tentu menarik untuk diperhatikan. Tentu sebagai penonton akan saling beradu pandangan karena masing-masing menganut suatu nilai tertentu yang beragam. Penciptaan kali ini merupakan usaha untuk menghadirkan konflik persoalan tersebut dalam sebuah pertunjukan. Dengan rangkaian cerita berlatarbelakang epos Mahabharta versi Jawa, sutradara berusaha membandingkan konteks masa lampau dengan kekinian. Pertunjukan dijadikan media berdialog baik antar penonton dengan pemain. Melalui bentuk pertunjukan semacam ini penonton tidak merasa digurui dan justru melakukan sumbang pemikiran melalui cara bercerita atau ikut bermain dalam pertunjukan yang berlangsung. Teater tidak lagi menjadi hal yang berjarak dengan penonton. Pertunjukan mengajak penonton 
untuk menentukan jalan cerita sekaligus pesan yang didapat dari hasil beradu pendapat. Melalui gaya pertunjukan semacam ini teater mampu menjadi sarana berkomunikasi yang lebih dekat serta menyerap aspirasi penonton secara langsung dan cepat.

Penonton merupakan sumber informasi melalui gesture yang ditampilkan. Melalui tubuhnya mereka merespon cerita sebagai gambaran pendapatnya. Penonton diberikan kesempatan untuk berekspresi secara langsung terhadap peristiwa yang diceritakan. Dari sini terlihat sudut pandang mereka sesuai latar belakang sosial maupun pengalamannya. Keterlibatan penonton serta pelaku cerita menciptakan alur cerita secara langsung yang menjadi sebuah kesimpulan tersendiri untuk dipelajari setelah pertunjukan usai. Pertunjukan menjadi sebuah cara ungkap pada persoalan yang disampaikan. Setelah pertunjukan usai muncul diskursus dan wacana-wacana baru untuk menjawab persoalan sosial dalam kehidupan bermasyarakat.

Seperti pendapat Plato pada buku Boal, (1974): Plato menggunakan ide Socrates tentang logo dan mengembangkannya (nya):

a. Idenya adalah visi intuitif yang kita miliki, dan justru karena itu intuitif, itu 'murni': pada kenyataannya tidak ada yang sempurna (seperti) segitiga, tetapi gagasan yang kita miliki tentang segitiga (bukan dari ini atau segitiga itu, yang bisa kita lihat dalam kenyataan, tetapi dari segitiga 'dalam umum'); ide itu sempurna. Orang yang mencintai, mewujudkan akting cinta, tetapi selalu tidak sempurna; apa yang sempurna adalah ide cinta. Semua ide sempurna; semua hal nyata dari realitas adalah tidak sempurna.

b. Ide adalah esensi dari hal-hal yang ada di dunia yang dapat dipahami ke indra; ide-ide tidak bisa dihancurkan, tak bisa bergerak, tidak berubah, abadi, dan abadi.

c. Pengetahuan terdiri dari meninggikan diri kita sendiri, melalui dialektika yaitu, melalui perdebatan ide yang diajukan dan ditentang, ide dan negasi dari ide-ide yang sama, yang ide-ide lain - dari dunia realitas yang masuk akal ke dunia ide-ide abadi. Pendakian ini adalah pengetahuan. Ide-ide dari kreator pertunjukan dan ide penonton yang murni akan mencoba dipertemukan dalam satu rangkaian pertunjukan.

Peristiwa seperti kisah di atas yang sudah sering terjadi di masa lampau hingga saat ini. Hal tersebut bisa kita saksikan dalam cerita atau dongeng di daerah-daerah sebagai cerita tertentu misalnya dalam Mahabarata. Pada epos Mahabarata versi Jawa ada kisah dimana Arjuna diperebutkan oleh dua perempuan, yaitu Subadra sebagai Istri yang syah dan Banowati sebagai pelakor. Dari cerita dengan latar belakang peristiwa perseteruan Kurawa dan Pandawa tersebut lalu diangkat menjadi sebuah pertunjukan teater berjudul Banowati sang Pelakor dengan gaya pertunjukan kekinian menggunakan metode pendekatan terhadap pemain secara aktif.

\section{Tinjauan Penciptaan}

Pementasan wayang kulit purwa Banowati Janji oleh Ki Dalang Nartosabdo dapat disaksikan melalui saluran Youtube (pranala: https://www.youtube.com/watch? v=IKXIr1ZnTKc\&feature=share). Kisah bercerita tentang Banowati yang menjalin hubungan asmara dengan Arjuna yang merupakan suami Sembadra, yang mana ia masih berstatus istri Duryudana. Kisah tersebut menjadi sumber ide cerita penyusunan alur naskah. 
Pementasan wayang kulit "Aswatama Nglandak" oleh Slamet Gundana Kalasinema dapat disaksikan melalui saluran Youtube (pranala: https://youtu.be/lx7cODCWMxE)

memberikan gambaran bagaimana relasi interteks terjadi antar unsur-unsur pendukung pertunjukan terhadap teks cerita berlatar kerajaan masa lampau. Beberapa ilustrasi musik maupun nyanyi dan tetembangan yang dekat dengan konteks kekinian menghadirkan nada-nada pentatonic bersanding dengan diatonic, kadang juga ditabrak dengan luwes oleh sang dalang secara langsung saat suluk ataupun nembang. Pocapan atau monolog sang dalang bernuansa jawa yang bercampur dengan logat ngapak khas Banyumasan budaya asal sang dalang, Slamet Gundana. Idiom-idiom masa lampau dan kekinian tampil menyusun pertunjukan dari awal hingga akhir sebagai sebuah kesatuan yang unik.

Pertunjukan Theatre of the Oppressed NYC: Sneak Peak via https://youtu.be/vi1HfSiMxCU memberi gambaran mengenai sebuah pertunjukan teater yang melibatkan penonton secara aktif. Penonton dipilih dari kalangan dengan latar belakang yang berkaitan dengan tema cerita, biasanya masyarakat umum yang memiliki sisi ketertindasan tertentu misalnya secara sosial. Penonton tidak memiliki latar belakang akting secara memadai namun dilatih melalui tahap-tahap tertentu agar tubuh mereka siap untuk bermain teater secara revolusioner atau dengan tempo yang relatif singkat.

Richard Schechner (1977) dalam bukunya Performance Theory menjelaskan mengenai proses-proses penciptaan sebuah performance art, pendekatan-pendekatan secara antropologi serta kedudukan sebuah performance art di tengah-tengah masyarakat. Pada beberapa bagian buku ini mengungkapkan fungsi-fungsi pertunjukan menurut periodesasi tertentu dari fungsinya sebagai ritual, penyampai pesan tertentu hingga sebuah sarana hiburan saja. Menurut Richard Schechner (1977):

"The drama is the domain of the author, the composer, scenarist, shaman; the script is the domain of the teacher, guru, master; the theater is the domain of the performers; the performance is the domain of the audience.

Clearly, in many situations, the author is also both guru and performer; in some situations the performers is also the audience..."

Terjemahan bebas:

"Drama merupakan domain dari penulis, komposer, penulis skenario, dukun; sastra merupakan domain pelatih, guru, master; teater merupakan domain dari para pemain; pertunjukan merupakan domain dari penonton. Jelasnya, dalam banyak situasi, penulis juga sekaligus guru dan pemain; dalam beberapa situasi para pemain juga penonton..."

Dalam proses penciptaan kali ini pemain kadang bertukar tempat dengan penonton. Sehingga penonton juga diberikan peran untuk menjadi pengarang yang menentukan arah perkembangan cerita. Fungsi pertunjukan bagi pihak-pihak atau kelompok tertentu dalam masyarakat perlu diketahui seperti halnya dalam proses kali ini yang membahas kalangan masyarakat tertentu dalam hal ini perempuan sebagai objek penciptannya. Pemikiran-pemikiran yang mendasari munculnya suatu bentuk pertunjukan teater harus dipahami sehingga tidak salah dalam menerapkan suatu metode dalam menciptakan sebuah karya seni.

Sedangkan dalam buku Theatre of the Opressed Augusto Boal (2000) berpendapat bahwa teater bukan untuk katarsis seperti teater Aristotelian maupun menumbuhkan pemikiran kritis saja seperti konsep Brechtian namun teater harus bisa 
menciptakan revolusi pada penontonnya. Dikatakan di dalamnya bahwa Teater kaum borjuis adalah teater yang mendikte masyarakat dengan segala peralatannya, khususnya aktor. Terdapat juga urutanurutan teknis pelaksanaan, alat serta ekspresi dari Teater yang Tertindas. Hal ini membuka kemungkinan bagi peserta / pembaca untuk memperluas batas-batas imajinasi mereka, memekaniskan kembali perilaku kebiasaan dan mendekonstruksi serta menganalisis struktur kekuasaan dan penindasan masyarakat. Buku tersebut menjadi berguna untuk acuan dalam menciptakan bentuk teater yang lebih akrab dan dinilai jujur dalam berpendapat, dalam hal ini tentang perempuan yang berelasi dengan fenomena pelakor.

\section{Teori Interteks}

Kajian intertekstual berangkat dari asumsi bahwa kapanpun karya itu ditulis tidak mungkin lahir dari situasi kekosongan budaya. Unsur budaya, termasuk semua konvensi dan tradisi di masyarakat dalam wujudnya yang khusus berupa teks-teks kesastraan yang ditulis sebelumnya. Karya sastra yang ditulis lebih kemudian biasanya mendasarkan diri pada karya-karya lain yang telah ada sebelumnya baik secara langsung maupun tidak, baik dengan cara meneruskan maupun menyimpangi (menolak, memutarbalikan esensi) konvensi (Nurgiyantoro, 1995).

Karya sastra yang dijadikan dasar penulisan bagi karya yang kemudian disebut sebagai hipogram 'hypogram' (Nurgiyanto, 1995). Wujud hipogram mungkin berupa penerusan konvensi, sesuatu yang telah bereksistensi, penyimpangan dan pemberontakan konvensi, pemutarbalikan esensi dan amanat teks sebelumnya (Nurgiyanto, 1995).

Adanya karya-karya yang ditransformasikan dalam penulisan karya sesudahnya ini menjadi perhatian utama kajian intertekstual. Adanya unsur hipogram dalam suatu karya mungkin disadari atau tidak disadari oleh pengarang. Kesadaran pengarang terhadap karya yang menjadi hipogramnya, mungkin berwujud dalam sikapnya yang meneruskan, atau sebaliknya menolak, konvensi yang berlaku sebelumnya (Nurgiyanto, 1995).

Prinsip intertekstualitas yang utama adalah prinsip memahami dan memberikan makna karya yang bersangkutan. Karya itu diprediksikan sebagai reaksi, penyerapan, atau transformasi dari karya-karya lain. Masalah intertekstual lebih dari sekedar pengaruh, ambilan, atau jiplakan melainkan bagaimana kita memperoleh makna sebuah karya secara penuh dalam kontrasnya dengan karya yang lain yang menjadi hipogramnya (Nurgiyanto, 1995).

Adanya hubungan intertekstual dapat dikaitkan dengan teori resepsi. Pada dasarnya pembacalah yang menentukan ada atau tidaknya kaitan antara teks yang satu dengan teks yang lain itu, unsur-unsur hipogram itu, berdasarkan persepsi, pemahaman, pengetahuan, dan pengalaman membaca teks-teks lain sebelumnya. Penunjukan terhadap adanya unsur hipogram pada suatu karya dari karya lain pada hakikatnya merupakan penerimaan atau reaksi pembaca (Nurgiyanto, 1995).

Menurut Jonathan Culler (1981), Julia Kristeva menjelaskan bahwa kajian intertekstual adalah kerja sejumlah pengetahuan yang memungkinkan sejumlah teks-teks memiliki makna: bahwa makna sebuah teks tergantung pada teks-teks lain yang telah menyerap dan mengubah bentuknya. Kristeva menyimpulkannya sebagai pengertian intersubjektivitas menjadi pengertian intertekstualitas. Sedangkan Yasraf A Piliang (2003) menyatakan bahwa, Kristeva melihat bahwa satu teks atau karya seni tidak berdiri sendiri, tidak mempunyai landasan 
atau kriteria dalam dirinya sendiri-tidak otonom.

Teks telah melalui perkembangan yang lebih lanjut dari yang semula berperan sebagai penanda suatu pesan saja maka kini telah berkembang dan memberi ruang yang lebih luas bagi pemberian makna oleh proses pembacaan. Minat strukturalisme untuk menarik simpul-simpul struktur dalam aktivitas berbahasa sebenarnya sudah menandakan kematian subjek. Dengan menelaah bahasa dalam kerangka sistem, tidak ada lagi yang menaungi subjek selain relasi-relasi yang yang mempertautkan berbagai sistem penandaan. Penekanan Saussure bahwa bahasa adalah bentuk, dan bukan substansi, mempertegas bahwa kematian subjek diambang mata, dan filsafat sudah tidak bisa lagi menoleh pada antroposentrisme. Pencerahan untuk mempertahankan dirinya sebagai penguasa tunggal dalam medan pemaknaan yang kian lebar dan tidak terbendung. Alternatif satusatunya adalah dengan menenggelamkan diri dalam arus tanda yang bergerak dan membiarkan kematian subjek dalam rangka memberikan ruang bagi munculnya maknamakna baru, Al-Fayyadl (2005).

\section{Teori Feminisme}

Feminisme adalah sebuah paham yang muncul ketika wanita menuntut untuk mendapatkan kesetaraan hak yang sama dengan pria. Istilah ini pertama kali digunakan di dalam debat politik di Perancis di akhir abad 19. Menurut June Hannam (2007) di dalam buku Feminism, kata feminisme bisa diartikan sebagai:

a. A recognition of an imbalance of power between the sexes, with woman in a subordinate role to men.

b. A belief that woman condition is sosial constructed and therefore can be changed.

c. An emphasis on female autonomy.

Terjemahan: a. Pengakuan tentang ketidakseimbangan kekuatan antara dua jenis kelamin, dengan peranan wanita berada dibawah pria.

b. Keyakinan bahwa kondisi wanita terbentuk secara sosial dan maka dari itu dapat diubah.

c. Penekanan pada otonomi wanita.

Awal abad ke-18 dapat disebut sebagai titik awal dalam sejarah feminisme. Walaupun sudah ada wanita yang melakukan debat untuk mendapat posisi yang diakui masyarakat, feminisme belum terlalu banyak berkembang pada saat itu. Pada saat itu yang bermunculan adalah para wanita yang menulis karya yang menunjukkan tuntutan mereka untuk mendapatkan persamaan hak, khususnya di dalam bidang pendidikan. Kemudian, Para wanita mulai tertarik dengan ide-ide baru yang muncul setelah revolusi Perancis. Mereka membayangkan kalau hubungan antar gender yang saat ini berlaku dihapuskan dan muncul dalam bentuk berbagai macam asosiasi yang ingin menghentikan dominasi pria dan menolak anggapan umum bagaimana menjadi seorang wanita saat itu. (Hannam, 2007)

Teori feminis mengamati bahwa banyak aspek kehidupan terlepas dari sex biologis dipahami dalam kualitas jender termasuk bahasa, kerja, peran keluarga, pendidikan, serta sosialisasi. Teori feminis bertujuan untuk membongkar kekuasaan dan batas-batas pembagian kekuasaan itu. Kekuasaan itu adalah penggolongan kelas atau status berdasarkan jenis kelamin (genderisasi). Teori feminis menekankan sifat opresif dan relasi gender. Sifat opresif adalah sifat yang keras dan menekan.

Feminis berasal dari kata "Femme" (woman), berarti perempuan (tunggal) yang berjuang untuk memperjuangkan hak-hak kaum perempuan (jamak) sebagai kelas sosial. (Ratna, 2004). Arti sederhana kajian 
sastra feminis adalah pengkaji memandang sastra dengan kesadaran khusus, kesadaran bahwa ada jenis kelamin yang banyak berhubungan dengan budaya, sastra, dan kehidupan kita.

Pada kesempatan kali ini pemahaman secara intertekstual bertujuan untuk menggali secara bebas makna-makna yang terkandung dalam sebuah teks yang berwujud kisah asmara Putri Banowati kepada Raden Arjuna. Apabila Roland Barthes, misalnya, menggali kualitas teks dengan cara menganggap karya sebagai anonimitas, yatim piatu, maka Kristeva justru dengan cara mengembalikannya ke dalam semesta budaya, meskipun tetap sebagai kebudayaan yang anonim, (Ratna, 2004). Kisah pelakor yang digambarkan tokoh putri Banowati dikembalikan pada penonton (pasif) yang berubah menjadi subjek (aktif).

\section{Teater yang Tertindas}

Di dalam Teater Kaum Tertindas, aktor tidak memiliki kuasa apa-apa untuk mendikte penonton mengenai nilai-nilai namun penontonlah yang menentukan nilanilai tersebut untuk kemudian dimasukan ke dalam panggung. Penonton tidak hanya dijadikan objek mati dalam pertunjukan namun penonton berperan sentral dalam pertunjukan karena dialah subjek pertunjukan sedangkan aktor nyaris dijadikan objek total oleh penonton.

Teater jenis ini adalah metode supaya penonton melakukan tindakan atau aksi yang nyata karena penonton tidak hanya dijadikan objek pasif tapi mereka juga turut menentukan jalan cerita, mengatur aktor, bahkan mereka bisa saja bermain di dalamnya (Spek-aktor). Karena penontonlah yang paling mengetahui apa yang mereka inginkan dalam sebuah permasalahan. Apalagi itu permasalahan yang menyangkut dirinya. Boal menyadari bahwa kita tak bisa menyampaikan pesan pada perempuan sebab kita lelaki, pada kulit hitam sebab kita kulit putih, pada petani sebab kita orang kota.

Tapi kita bisa bantu menemukan cara berjuang mereka sendiri. Kurang lebih digambarkan seperti diagram koersif Aristoteles dibawah ini:

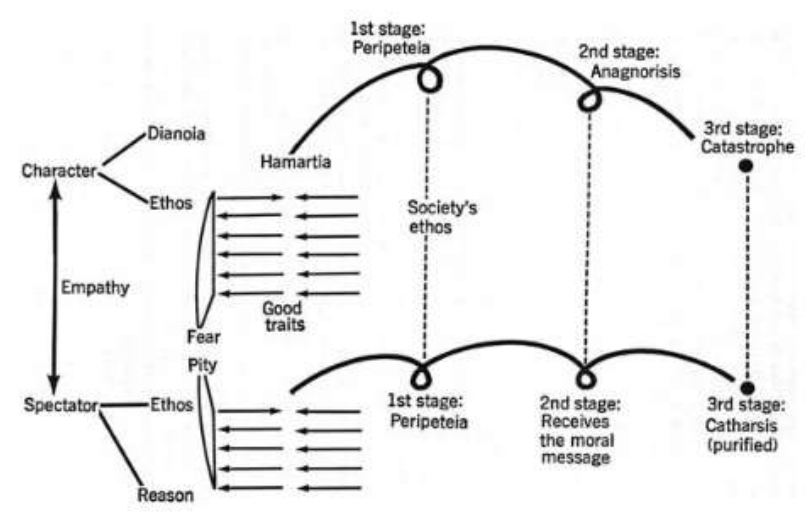

Gambar 1. Diagram koersif Aristoteles

"First Stage: Stimulation of the hamartia; the character follows an ascending path toward happiness, accompanied empathically by the spectator. Then comes a moment of reversal: the character, with the spectator, starts to move from happiness toward misfortune; fall of the hero. Second Stage: The character recognises his error - Anagnorisis. Through the empathic relationship dianoia-reason, the spectator recognises his own error, his own hamartia, his own anticonsti-tutional flaw. Third Stage: Catastrophe; the character suffers the consequences of his error, in a violent form, with his own death or with the death of loved ones. Catharsis: The spectator, terrified by the spectacle of the catastrophe, is purifi ed of his hamartia" (Boal, 1974).

Tahap pertama: Stimulasi hamartia; tokoh melalui perjalanan menanjak menuju kebahagiaan, bersamaan dengan munculnya empati penonton. Kemudian muncul 
peristiwa pembalikan: tokoh, dengan penonton, mulai bergerak dari situasi kebahagiaan menuju kemalangan; kemalangan sang tokoh pahlawan. Tahap Kedua: Tokoh mengakui kesalahannyaAnagnorisis. Melalui hubungan empatik dianoia-alasan, penonton mengakui kesalahannya sendiri, hamartia sendiri, cacat anticonsti-tutional sendiri. Tahap Ketiga: Bencana; Tokoh menderita akibat kesalahannya, dalam bentuk kekerasan, dengan kematiannya sendiri atau dengan kematian orang yang dicintai. Pembersihan: Penonton, yang ketakutan oleh peristiwa tontonan malapetaka, dimurnikan hamartianya.

Dari hal tersebut Boal sadar bahwa penonton sendirilah yang mengetahui jalan keluar yang pas untuk kondisi mereka dan nilai-nilai apa saja yang bisa mereka pegang. Teater konvensional bagi Boal terlalu memaksakan kehendaknya pada sebuah pemikiran tertentu, karena pada kenyataanya setiap tempat memiliki kebudayaan dan adat yang berbeda maka mereka juga memegang nilai-nilai yang berbeda pula. Teater Kaum Tertindas melibatkan orang-orang tertentu yang terpilih, berisi refleksi dan dialog kritis, serta proses untuk meraih kebebasan. Melalui Teater Orang Tertindas kita dapat lebih memahami diri kita sendiri, komunitas kita dan dunia kita.

\section{Metode Penciptaan dan Data}

Pada metode yang dikembangkan Augusto Boal terdapat beberapa hal yang perlu diperhatikan. Yang paling utama adalah merubah penonton (objek) menjadi pemain (subjek). Proses ini bisa dikatakan revolusioner karena rata-rata penonton yang dijadikan subjek bukan pemain teater yang professional, meskipun dalam penciptaan kali ini tetap melibatkan beberapa aktor yang sudah berpengalaman. Mereka berfungsi sebagai fasilitator saja atau partner dalam bermain. Bagi penonton yang dilibatkan tentu hal tersebut merupakan pengalaman yang membuat tubuhnya berubah dengan tujuan menyesuaikan diri dalam waktu yang singkat.

Untuk mencapai kondisi yang revolusioner pada tubuh penonton, Boal menggunakan beberapa metode. Sebenarnya metode-metode ini mirip dengan teater game. Metode-metode yang digunakan Boal rata-rata mungkin sudah pernah kita pelajari dalam latihan dasar teater sebelum memasuki naskah, hanya saja diterapkan pada saat pertunjukan pada penonton.

\section{Tahap I}

a. Menyusun draft cerita seputar kisah asmara Putri Banowati dan Raden Arjuna

b. Mempersiapkan aktor yang menjadi peraga dan fasilitator dengan berlatih menciptakan adegan

c. Merancang unsur artistik berupa musik dan tata panggung

d. Melakukan rehearsal secara utuh sebelum berte,mu dengan penonton

2. Tahap II

a. Penonton dan pemain diperkenalkan pada cerita tentang pelakor

b. Penonton melakukan permainan bersama dengan penonton lainnya yang dipandu oleh pemain yang sudah berpengalaman dalam dunia akting.

3. Tahap III

a. Pemain memulai menciptakan peristiwa seperti yang ada pada draft dengan bentuk sinopsis tiap-tiap adegan.

b. Pada puncak peristiwa di tiap-tiap adegan penonton dipersilahkan untuk berkomentar dan bertindak ke atas panggung menanggapi peristiwa cerita yang berlangsung.

4. Tahap IV

Penonton dan fasilitator menyudahi cerita pada kesimpulan yang dibuat bersama-sama. 


\section{Hasil dan Pembahasan}

1. Tahap I

a. Menyusun draft cerita seputar kisah asmara Putri Banowati dan Raden Arjuna. Draft disusun sedemikian rupa sehingga adegan demi adegan mengacu pada draft agar peristiwa tidak berkembang secara liar dan tak terkendali.

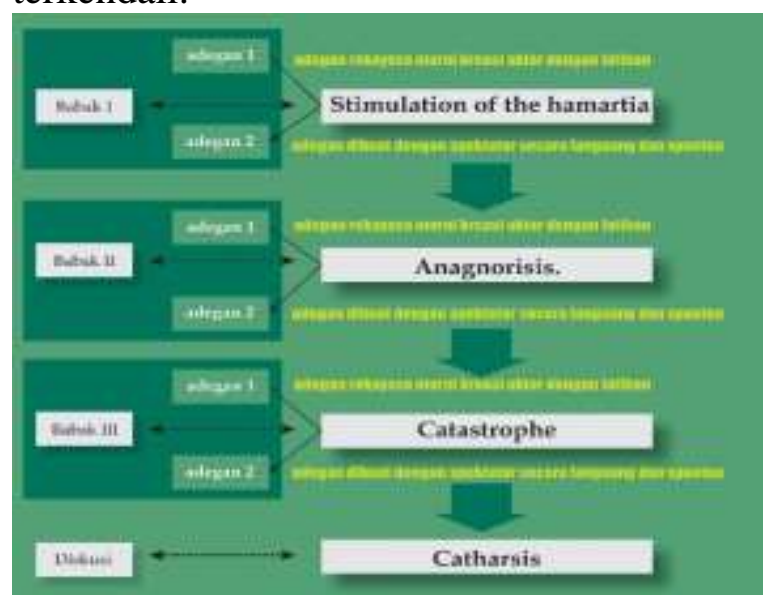

Gambar 2. Struktur draft Banowati Sang Pelakor (Foto doc Wahid 2018)

Meski demikian draft bersifat terbuka dalam memberikan ruang berkreasi bagi actor dan sutradara untuk mengembangkan adegan agar lebih menarik. Tujuan lain dari draft adalah memberikan stimulasi bagi penonton dan spectator untuk mulai focus pada persoalan yang diangkat melalui adegan satu pada masing-masing babak.

b. Mempersiapkan aktor yang menjadi peraga dan fasilitator dengan berlatih menciptakan adegan. Pada tahap ini, aktor harus tahu benar mengenai duduk persoalan yang akan dibawakan. Untuk itu perlu berdiskusi dan menentukan alur cerita.

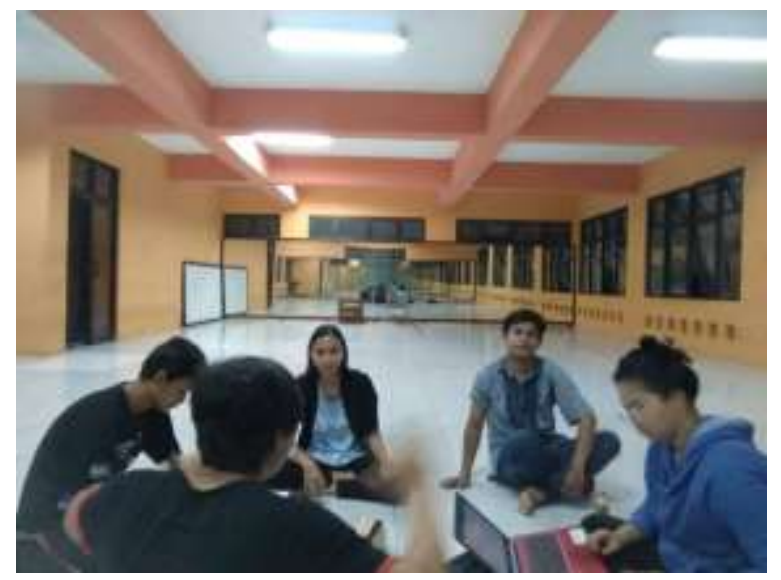

Gambar 3. Berdiskusi menentukan cerita

Alur cerita diciptakan dengan cara membuat adegan dan menuliskannya kemudian atau sebalikknya yaitu membuat draft dan mempraktekkannya. Latihan dilakukan dua kali dalam satu minggu masing-masing 3 sampai 4 jam.

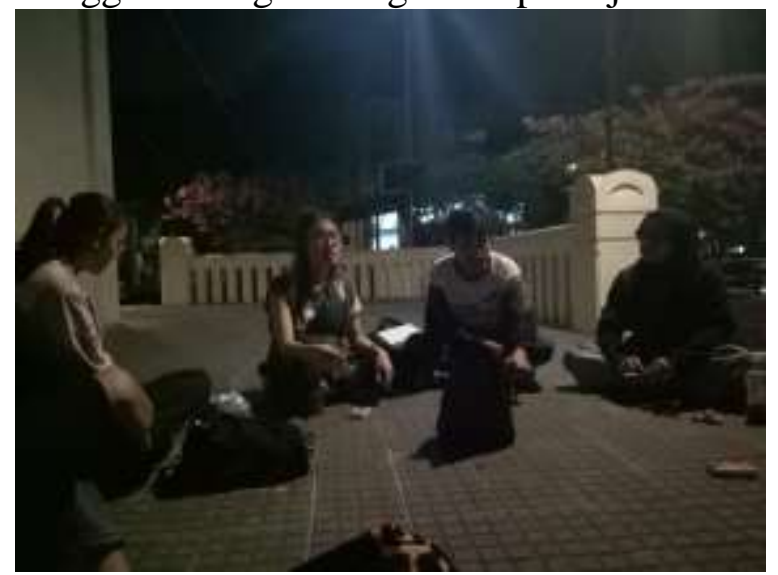

Gambar 4. Berlatih membuat adegan.

(Foto doc Wahid, 2018)

c. Merancang unsur artistik berupa musik dan tata panggung. Tata artistik salah satu unsurnya adalah musik. Music diperlukan untuk membentuk menciptakan suasana dan dramatisasi irama permainan. Selain itu beberapa aktor juga bisa mengekspresikan emosi dalam cerita dengan menggunakan music secara langsung atau live. Latihan dilakukan dengan memberikan arahan 
kepada pemain untuk mengingat peristiwa tertentu yang ada hubungannya dengan tema cerita. Setelah itu Ia akan diberi kesempatan dalam memilih alat ekspresinya. Cara berekspresi yang demikian diberi ruang dalam pementasan dengan tujuan menambah variasi permainan agar pertunjukan tidak membosankan. Sementara untuk pemain atau aktor yang tidak berlatar belakang pemusik akan diberi keleluasaan dengan berakting.

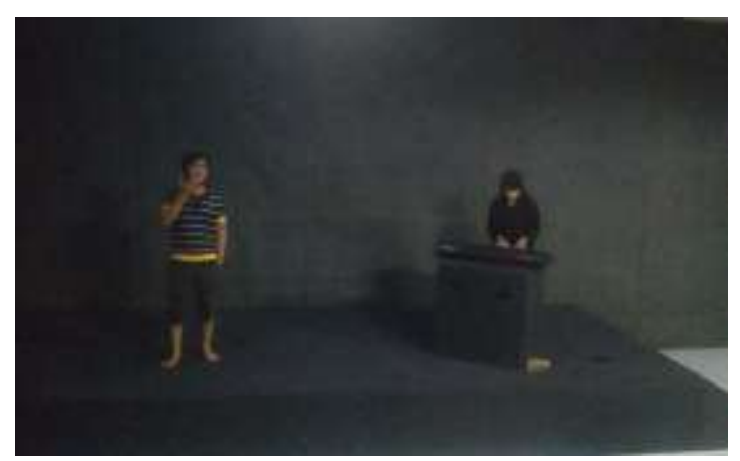

Gambar 5. berlatih berekspresi dengan musik. (Foto doc Wahid 2018)

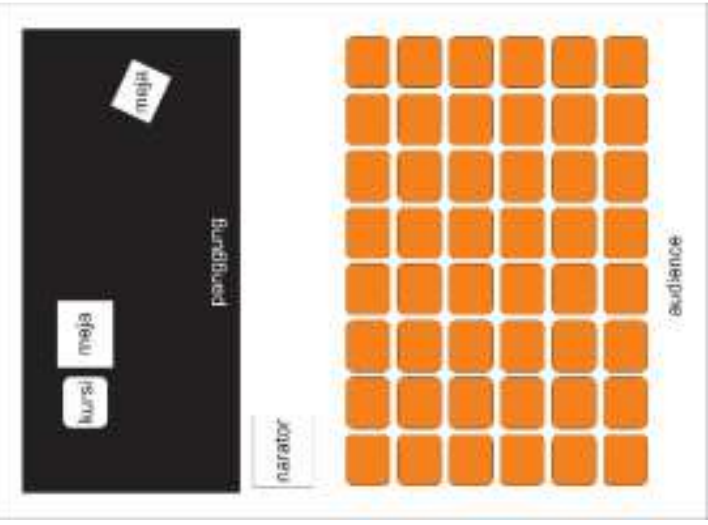

Gambar 6. area permainan (Foto doc Wahid, 2018)

d. Melakukan rehearsal secara utuh sebelum bertemu dengan penonton

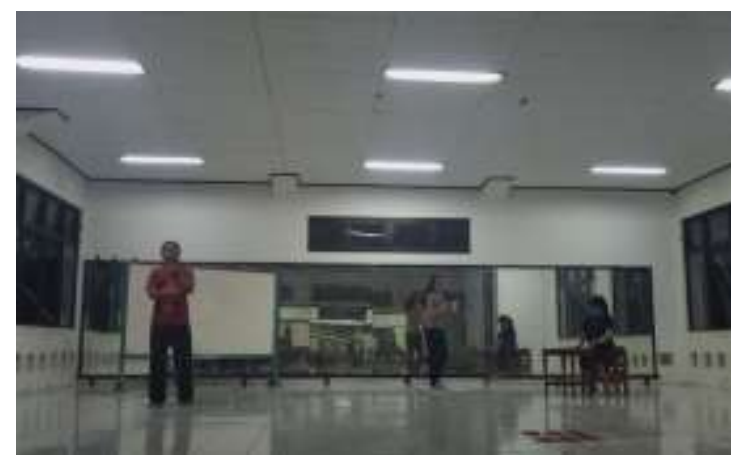

Gambar 7. latihan secara keseluruhan (Foto doc Wahid 2018)

Setelah semua adegan dibuat maka mulailah merangkai semua adegan dengan urut. Selain adegan pertunjukan yang dilakukan oleh aktor juga berlatih dalam menciptakan adegan bersama partisipan (spectator). Latihan dilakukan dengan pengganti partisipan secara acak dan beragam. Hal ini bermaksud untuk melihat kemungkinan reaksi partisipan pada saat pertunjukan.

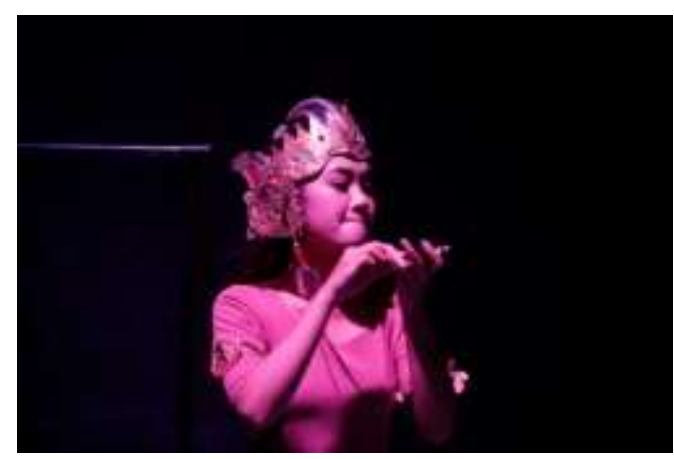

Gambar 8. Perwujudan rias tokoh Subadra (Foto doc Wahid 2018).

\section{Tahap II}

Penonton dan pemain diperkenalkan ulang pada cerita tentang pelakor. Pembawa acara membuka pertunjukan dengan memperkenalkan diri dan menerangkan persoalan secara ringkas. Penonton diberitahu akan peran dan fungsinya sebagai bagian yang terpisahkan dari pertunjukan yang akan dilakukan. 


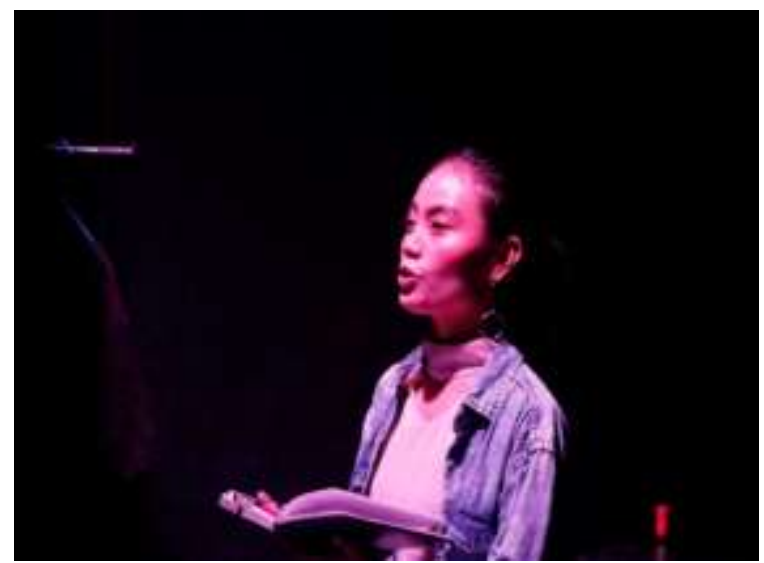

Gambar 9. Peran Pembawa Cerita (Foto doc Wahid 2018)

Penonton melakukan permainan bersama dengan penonton lainnya yang dipandu oleh pemain yang sudah berpengalaman dalam dunia akting. Setelah ada seorang atau beberapa partisipan yang bersedia naik ke atas panggung maka narator mundur ke belakang pentas. Partisipan yang terpilih kemudian harus beradu acting secara improvisasi dengan para pemain yang sudah dipersiapkan. Aksi-reaksi partisipan dalam menghadapi laku yang dijalankan actor menjadi penting untuk diperhatikan. Partisipan akan mempunyai reaksi yang berlain-lainan antara satu dengan lainnya.

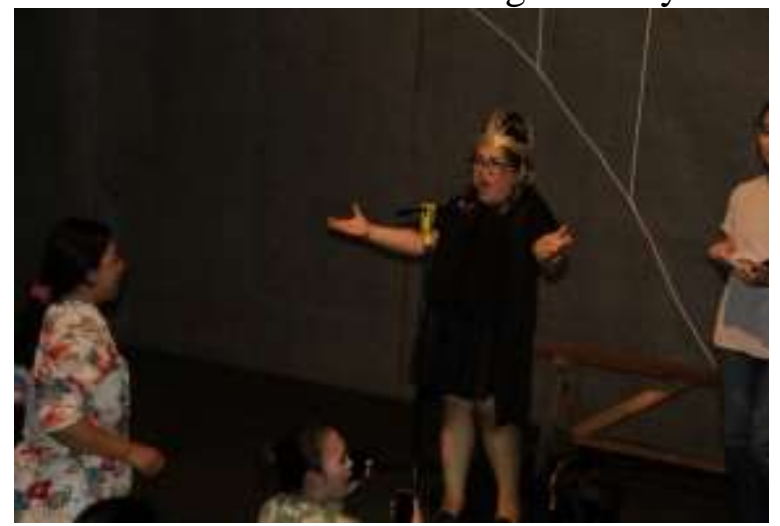

Gambar 10. Tokoh Banowati (Foto doc Wahid 2018).

\section{Tahap III}

Pemain memulai menciptakan peristiwa seperti yang ada pada draft dengan bentuk sinopsis tiap-tiap adegan. Penonton atau partisipan diperkenalkan [pada persoalan melalui fragmen pendek dari tokoh - tokoh dalam kisah percintaan segitiga Banowati-Arjuna-Subadra. Dengan dibantu oleh seorang Narator yang berperan juga sebagai pembawa acara, penonton sedikit demi sedikit digiring untuk mengikuti instruksi pembawa acara agar mau tampil di atas pentas.

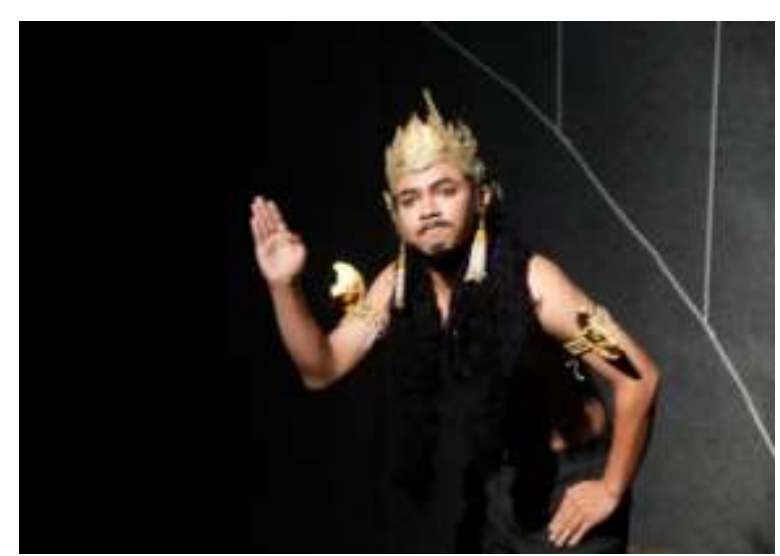

Gambar 11. Tokoh Duryudana (Foto doc Wahid 2018)

Pada puncak peristiwa di tiap-tiap adegan penonton dipersilahkan untuk berkomentar dan bertindak ke atas panggung menanggapi peristiwa cerita yang berlangsung.

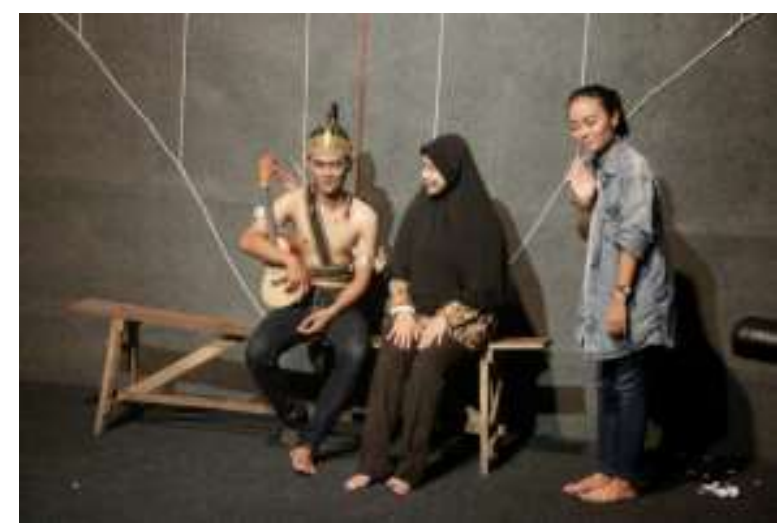

Gambar 12. Partisipan bersiap melakukan permainan di atas panggung dengan actor

(Foto doc Wahid 2018)

\section{Tahap IV}

Penonton dan fasilitator menyudahi cerita pada kesimpulan yang dibuat 
bersama-sama. Setelah sebelumnya berdiskusi dan mencapai penyadaran bahwa persolan yang ada mustinya dilihat dari berbagai sudut pandang agar tercipta harmoni dan hilang egosentris di pikiran masing-masing individu. Harapan yang kemudian di pupuk pada tiap individu adalah mampu saling menghargai individu lain sebelum menghakimi tanpa tau duduk permasalahan yang ada hanya karena tertutup jalan komunikasinya.

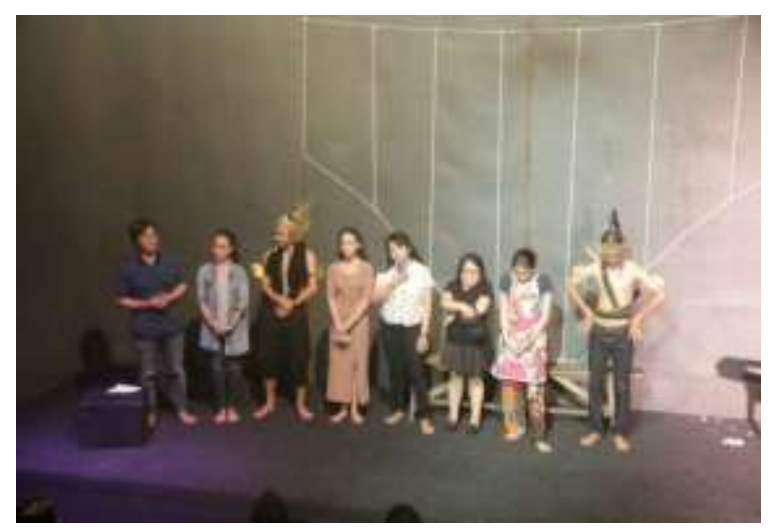

Gambar 13. Sutradara dan para pemain

(Foto doc Wahid 2018)

\section{Simpulan}

Pada proses penciptaan seni teater kali ini terdapat kendala yang sudah diperhitungkan sebelumnya. Beberapa kendala tersebut antara lain menemukan dan mengajak partisipan untuk berperan aktif, terlebih pada partisipan dengan pengalaman sebagai pelakor. Hal ini disebabkan oleh stigma buruk yang menempel di masyarakat tentang posisi pelakor itu sendiri. Sedangkan kesulitan kedua adalah pada partisipan dengan pengalaman sebagai lelaki yang dinilai tidak setia. Dan sebaliknya partisipan yang berpengalaman sebagai lelaki justru memiliki kepercayaan diri lebih tinggi. Sebagian mereka beranggapan bahwa memiliki lebih dari satu pasangan adalah hak spesial yang dimiliki laki-laki tetapi tidak pada perempuan. Hal itu juga diamini oleh sebagian partisipan perempuan.
Partisipan membutuhkan persiapan yang matang untuk berani tampil diatas panggung. Meskipun beberapa partisipan ternyata justru bersemangat dan menyatakan kelegaanya telah mampu mengungkapkan isi atau unek-unek yang selama ini dia pendam dalam pikirannya. Hal tersebut bisa terjadi karena atmosfir pertunjukan yang hangat tercipta serta peran pembawa acara yang komunikatif dalam memancing perasaan dan pemikiran peserta pertunjukan.

Pentas ini membutuhkan ruang yang tidak begitu terbuka karena jumlah partisipan dibatasi agar persoalan dan durasi bisa dibatasi pula. Dengan ruang yang lebih terbuka dikhawatirkan partisipan kurang nyaman untuk berekspresi. Proses penciptaan teater dengan gaya semacam ini mampu menciptakan komunikasi yang unik antara partisipan, actor dan pengamat. Hal tersebut bisa dimanfaatkan untuk mendalami sebuah persoalan sosial dimasyarakat yang mungkin susah diungkapkan dengan melakukan wawancara secara langsung terutama jika berbenturan dengan nilai-nilai dan tabu yang terlanjur dianut dengan ketat di suatu lingkungan.

\section{Daftar Pustaka}

Al-Fayyadl. (2005). Muhammad. Derrida. Yogyakarta: LKis.

Boal, A. (2000). Theatre of the Opressed. London: Pluto Press.

Culler, J. (1981). The Pursuit of Signs, Semiotics, Literature, Deconstruction, London and Henley: Routledge \& Kegan Paul.

Hannam, J. (2007). Feminism (In Focus Short Histories Of Big Ideas Series). Pearson/Longman: University of Virginia

Nurgiyantoro, B. (1995). Teori Pengkajian Fiksi. Yogyakarta: Gajah Mada University Press. 
Piliang, Y.A. (2003). Hipersemiotika, Tafsir Cultural Studies Atas Matinya Makna. Yogyakarta: Jalasutra.

Ratna, N. K. (2011). Teori, Metode, dan Teknik Penciptaan Sastra, Dari Strukturalisme Hingga Postrukturalisme. Yogyakarta: Pustaka Pelajar.

Schechner, R. (1977). Performance Theory. New York: Routledge. 